\title{
Spatial Distribution of Economic Activities, Growth Policies and Externalities in Developing Countries
}

\author{
Mohamed Ali Labidi \\ Laboratory of Valorization of Natural and Cultural Heritage (LVNH) \\ Facyulty of Law, Economics and Management of Jendouba, University of Jendouba, Jendouba, Tunisia
}

\begin{abstract}
In the developing countries, development policies have generated an uneven development. The economic activities are unevenly distributed and regional disparities are becoming increasingly noticeable. The role of growth policies is decisive in bridging spatial inequalities and enabling less-favored regions to catch up on their economic backwardness. The objective of this article is to clarify the stakes and levers of local growth policies in the current context of the developing countries and to understand the relationship between externalities and agglomeration of firms in order to influence the parameters of externalities and to allow a better distribution of economic activities in space.
\end{abstract}

Keywords: Firm; Growth; Agglomeration Economies; Policy Making

\section{Introduction}

In developing countries, the economic activities are unevenly distributed, hence the economic growth becomes geographically unequal. Public authorities must play a significant role to ensure that the economic catch-up process will be sufficiently rapid. For this, they must implement policies of local growth to correct spatial inequalities and to help the regions which have been less favored by nature and history.

The spatial distribution of the economic activities is not based solely on cost considerations. The company combines multiple resources in skills, informal relationships, technologies, etc. These resources are not present everywhere, which generates an unequal distribution of the economic activities and therefore an uneven regional development (Puga, 1999; Borowiecki, 2014).

The concentration of firms in the same area induces advantages that can be explained in quantitative terms by improving the efficiency of division of labor, cutting production costs and raising factor productivity by resulting economics of scales. Thus, the dynamics location of economic activities as well as of growth, relies heavily on the dissemination of information and especially on the transmission of tacit knowledge held by workers (Mori and Smith, 2015; Delgado and al., 2016).

Spatial configurations of economic activities are considered to be the result of a process that includes agglomeration forces and dispersal forces. The models of the new geographical economy analyze the conjunction of the imperfect competition, the increasing returns to scale and the result of financial externalities to explain the uneqal distribution of economic activities in space (Krugman, 1991a; Krugman and Venables, 1995).

Increasing returns to scale generate an interdependence between the location of firms and that of consumers. These increasing localized scale returns may be either internal or external to the firm. The external effects of agglomeration result mainly from the labor market. The internal sources of agglomeration derive from the price of factors of production and conditions of access to the market. Moreover, the diseconomies of agglomeration trigger the dispersion of the economic activities in space (Henderson and al., 2001; Mori and Smith, 2015; Billings and Johnson, 2016)

In the developing countries, the spatial distribution of economic activities raises a very important question: how can local growth policies fill the industrial gap in regions with low economic activity?

The unequal distribution of the economic activities implies that firms determine their choice of location in an endogenous way, because the concentration of firms often involves externalities. Thus we will discuss the relationship of externalities and the agglomeration of firms in order to influence the parameters of externalities and allow a better distribution of the economic activities in space.

\section{Economic disparity in developing countries}

The economic policy aims to reduce the spatial inequalities resulting from the spatial distribution of the economic activities. The main issue is that the speed and the extent of the spread of growth will depend on the degree of integration of the economic fabric, transport and communication networks, and many other factors: sectoral coherence, entrepreneurial dynamism, legal framework, economic density, etc (Barde, 2010; Caragliu and Nijkamp, 2016). The growth may not spread in some directions where stoppage effects will occur and, as a result, some regions will be deprived of the collective wealth production effort (Esfahani and Ramírez, 2003; Borowiecki, 2014).

The economic environment, and in particular the conditions that directly affect private investment, seems to play an important role in the spatial distribution of the economic activities. Indeed, investment depends firmly on 
the macroeconomic atmosphere. The economic downturn and the worsening macroeconomic imbalances have led to a decline in investment, which has in, its turn, led various developing countries to embark on a macroeconomic reform aiming at creating a stable and predictable environment.

\subsection{Economic policy reform}

The developing countries today differ from one another and could not be described by a simple list of typical characteristics. In the early 1960s, these countries were much more similar in their approach to trade policy, macroeconomic policy and modes of intervention in the economy.

Since the 1970s, there has been a reorientation of the countries' economic policy to a liberal direction. The economic downturn and the worsening macroeconomic imbalances have led to a decline in investment, which has led various developing countries to embark on macroeconomic reforms.

The developing countries abandoned their policy of import substitution and embarked on development based on export effort, trying at the same time to restrict the government's control over the economy, to break the high chronic inflation and to be opened up to private flows of capital.

During the 1980s, the economic downturn and the worsening macroeconomic imbalances resulted in a decline in investment, which prompted various developing countries to reform growth policies.

The strategy initiated is to decentralize the economy, a condition deemed necessary for the reinforcement of the private initiative in terms of investment and resumption of growth. The overall expected effects of the structural adjustment program are reflected in the improvement in the current account balance, the reduction of budget deficits and the increase in the overall productivity.

The presumption of growth policies of the developing countries is to create a suitable environment for the promotion of private investment. Improving the overall climate requires the removal of barriers, essentially the tariffs of the protectionist regime and the adoption of a more liberal and more private-sector investment regime (Fosu, 2013; Salinas and al., 2015)

The disengagement of the state from activities where the private initiative exists, creates a promising environment for the private sector. The government has made privatization as its strategic priority of private sector development and an important instrument for strengthening the economy and rehabilitating market mechanisms. Moreover, privatization appears to be a response to the various pressures on economies: shrinking of state resources, external debt and budget deficits.

Growth policies aim at creating a better distribution of the benefits of growth between the different regions and the limitation of disparities between them. They seek to consolidate economic development by eliminating certain social costs linked to non-intervention, such as the costs of not investing in regions that offer sufficient territorial capital and project profitability which other regions can offer (Prager and Thisse, 2009).

The economic changes that have marked the international relations which in their turn are, now, marked by the globalization of the economy and the emergence of powerful regional groups and unions. All of this has led public actors to redefine the development strategy by integrating the national economy in the global economy through a policy of liberalization and a gradual decline in protectionism (Fosu, 2013; Sala and Trivín, 2014). This new period requires the development of industrial integration and the strengthening of the technological basis and lay the foundations for an industrial fabric that will help consolidate the pace of growth.

The upgrading program was designed to strengthen the competitiveness of the industry under a new economic environment marked by increased competition. Often, this program contains, on the one hand, the upgrading of the industrial environment in order to design an appropriate atmosphere, which allows the increase of industrial investment. It also includes provisions to support industrial enterprises in order to facilitate their adaptation to the market requirements, the understanding of the technology, the follow-up of the liberalization policy, the encouragement of foreign direct investment and the development of industrial areas.

In many developing countries the industrial sector's development strategy is manifested in the adoption of economic policies which aim at improving capacity utilization and at controlling production costs in order to strengthen the competitiveness of industrial enterprises and to facilitate their access to foreign markets, to promote exportation, to strengthen partnership and to adapt incentives granted by the state to new demands in the development of the industrial sector. It also involves the strengthening of the rates of supervision of industrial enterprises and the basic infrastructure in the regions to encourage private initiatives (Sala and Trivín, 2014).

The reform measures have in some way, stabilized the economy and avoided worsening imbalances in public finances and external payments. This performance at the global level was accompanied by worsening regional disparities, which had the effect of transforming the economy of developing countries into a dualistic economy.

\subsection{Spatial distribution of economic activities}

The spatial distribution of the economic activities is often seen as the result of a process involving two types of opposing forces, agglomeration forces and dispersal forces. Indeed, there are costs and benefits for one firm to locate itself close to other firms, which affects the costs and benefits of other firms through congestion and 
concentration effects. In the developing countries, despite the proliferation of development strategies, there is a strengthening of regional imbalances (McCormick, 1999; Rey and Janikas, 2005; Mori and Smith, 2015). The industrialization movement has grown in large urban areas.

Through observing the geographical distribution of the economic activities we notice that the activities tend to agglomerate in space. In each country, the major urban areas share the national wealth. The unequal distribution of economic activities is not confined to the industrialized countries. Spatial concentration is very noticeable in many developing countries (Fritsch and Slavtchev, 2010; Borowiecki, 2014).

The two facts which characterize the geographical distribution of the economic activities in the developing countries are the unequal geographical distribution of the economic activities and their unequal sectoral distribution.

The spatial distribution of economic activities in the context of developing countries reflects, in its main features, the classical center-periphery model. Historically, this model is the result of colonization. Thus, we can consider that the trends of the past have largely influenced the modalities of the present development of the developing countries and in particular those of the spatial distribution of the economic activities.

The capitals of the developing countries accumulated two strategic positions: the status of political capital was added as a point of contact with the rest of the world. Almost all the branches, branches or subsidiaries of foreign industrial groups will be localized in the capitals.

Small industrialists were doubly encouraged to locate their activities in the capital or in neighboring areas. Thus, the concentration of the population in the capital resulted in the concentration of their market and the imperative need to import the majority of their inputs (Barde, 2010).

An examination of the spatial distribution of activities in the developing countries shows that there is a high concentration in a limited number of space units. Large urban areas are the only viable locations of the activities for a large number of firms (Kubo, 1995; Rosenthal, 2001; Azzoni, 2001). The location of companies is no longer at random, it is carried out according to the size of the companies and the nature of their activities (Billings and Johnson, 2016). Obviously, the companies tend to be located in large areas where there is a large local market that allows the manufacturing and the sale of a wide variety of products (Barde, 2010).

The industrial units created in the areas of low economic density in order to fill the industrial gap have not produced the expected results. The weakness of industrialization and the physical infrastructure is one of the most important factors in all developing countries. The industrialization movement has been intensified in the capital and in the coastal regions to the detriment of other regions.

In general, the economic policy in developing countries has oscillated between promoting domestic investment through capital subsidies and tax incentives and promoting foreign direct investment through tax exemptions. Thus, through the granting of fiscal and monetary incentives, the public authorities have sought to influence the spatial distribution of the economic activities in order to make the low-density areas more attractive. It may be considered that development efforts have not been up to the size of the imbalance. The failure of growth policies to reduce regional imbalances reflects the limitations of the development strategies of most developing countries.

\section{Local growth policies in developing countries}

The economic growth does not always occur with the same intensity. Governments rely on the local growth policies with the aim of orienting investments to disadvantaged regions where the density of economic activities is low (Zhu and al., 2017).

Since the 1980s the dominant growth policy in developing countries has opted for attractiveness policies at both national and local levels in order to attract foreign investment in search of localization sites. These policies rely primarily on the financial and the fiscal incentives. They include different forms of tax reduction or exemption, total or partial financing of land or infrastructure, subsidies, preferential loans and commercial privileges.

The favorable perception of foreign investment stems in particular from the fact that these investments allow a non-debt-generating financial flow and the technological transfers. They constitute, in times of uncertainty or crisis, a more stable resource than other capital (Borensztein and al., 1994; Bell and Pavitt, 1996; Blomstrom and Kokko, 2003).

However, incentive policies are not subject to co-ordination only under certain regional agreements, and at the multinational level there is no rule limiting international competition by incentives (Kokko, 1996). When all governments uncooperatively develop such measures, it becomes difficult for a state not to participate, at least at the same level as the others.

The risk that arises from incentive policies is to attract investment of low specific benefit and therefore this situation generates little externalities and a social gain. The growth policy needs to be reconsidered because financial or fiscal benefits must be granted according to sectoral or technological intensity criteria based on the assessment of the magnitude of the external effects of investment on the economy.

The concentration of the economic activity plays a central role in the economic growth, but, at the same time, 
it has costs. It is therefore preferable neither to try to over-force the spontaneous mechanisms of the market nor to oppose the tendency to agglomeration of activities and people by policies that are too restrictive for the growth of the main cities (Glaeser and al., 1992; Borowiecki, 2014). Public policies must have a direct impact on business location decisions without, however, restricting areas with high industrial density. In fact, it is a matter of implemeting positive discrimination strategies in order to avoid the risk that public policies aim at improving the economic performance by influencing the geography of economic activities. This produces opposite effects to those expected and reinforces rather than mitigates spatial gaps (Martin, 1999; Zhu and al., 2017). The strengths and weaknesses of each area must first be identified in order to determine the most appropriate areas for public action. This leads to a questioning of the classic patterns of state intervention. The lessons of geographical economics and the theory of endogenous growth can therefore help to set limits.

Often, the policies adopted to control spatial inequalities favor a more balanced distribution of the economic activity at the national level, affecting directly localization decisions. The dispersion of activities reduces, consequently, the benefits generated by agglomeration economies (Vermeulen, 2017). This strategy can reinforce the difficulties faced by the companies namely the difficulty of access to knowledge and the lack of human resources. In addition, industries located in urban areas are subject to rapid flows of innovation. The aim is therefore to implement an innovation policy that will have a positive effect on the decision to innovate small and medium-sized enterprises.

Unlike the early neoclassical models, endogenous growth theory has placed a great deal of importance on the interaction between economic growth and public policy. Indeed, one of the most robust result of the empirical studies is that investment in infrastructure could have an impact on the long-term growth rates.

The infrastructure may be a factor that aggravates regional disparity. Generally, the infrastructures roles twofold in the economy: on the one hand, they provide essential services for the conduct of productive activity. On the other hand, they generate significant positive external effects over the whole economic activity by facilitating the mobility of the economic agents and the junction of the different markets. The infrastructure programmes must therefore focus on both the services they produce and the spillover effects they generate on the economic activity. The public infrastructure needs the appropriate public intervention in terms of financing and control, in order to produce and distribute the different effects equally.

Land-use planning policies should support spatial concentration of the economic activities to contribute to the growth. The explanation lies in the emergence of close links between the actors, which in turn would favor the emergence of positive externalities. Land use policies have oscillated between two options: a voluntarist option and a strategy to accompaniment the behavior of the economic agents (Thisse and Prager, 2009). The voluntarist option seeks to directly influence the choice of the location of key economic agents. The choice of the zones to be favored and those that must be slowed down, is the result of a political and administrative process which seeks to shape the region according to its preferences. The public authorities must reduce the obstacles to the territorial deconcentration of activities to achieve sufficient critical mass and engage in a virtuous process of economic agglomeration (Martin and Ottaviano, 2001).

The main idea of the two development strategies lies in the rejection of the market as a unique way of organizing economic activities, because market forces lead to unequal distribution of activities. Thus, to remain passive in the face of metropolisation would risk to contributing to the exclusión of entire regions from the production effort of collective wealth and would result into considerable economic and social costs. It is, therefore, essential to develop an active policy to promote the potential of low-density regions (Prager and Thisse, 2009).

Developing countries are experiencing great weaknesses in the national science systems. Oftent, this situation is due to the weakness of private and public research efforts and inadequate technological performance. The technological backwardness in the developing countries can also be explained by the limited resources devoted to research and innovation and by the organizational weaknesses of research and innovation.

It is becoming increasingly legitimate to introduce investment incentives and to create a regulatory, legal and financial framework to foster public research and multiply the training effects (Baldwin and al., 2001).

\section{Externalities and spatial distribution of economic activities}

Externalities play an important role in explaining the geography of the economic activities. Indeed, the consideration of the spatial dimension in the analysis of the geography of the economic activities is based on the assumptions of the arbitration of transport costs, the increasing returns and the spatial dimension of externalities (Mori and Smith, 2015; Vermeulen, 2017).

Agglomeration economies represent the main element of the spatial and urban economy in explaining the spatial distribution of the economic activities. It has been largely proven that the physical proximity of firms offers additional benefits to production (Caragliu and Nijkamp, 2016). The externalities inherent in the concentration of industries raise from the availability of specialized inputs and services, the formation of a labor market, the exchange of information and the diffusion of technologies (Fujita and al., 1999; Kogler and al., 2017).

Spatial configurations of the economic activities are considered to be the result of a process that includes 
agglomeration forces and dispersal forces. The models of the new geographical economy (Krugman and Venables, 1995; Fujita and al., 1999) analyze the conjunction of imperfect competition, increasing returns to scale and pecuniary externalities to explain the distribution of the economic activities in space. Indeed, the increasing returns to scale generate an interdependence between the location of firms and the location of consumers. These increasing localized scale returns may be internal or external to the firm (Henderson and al., 2001). The external effects of agglomeration result mainly from the labor market. The internal sources of agglomeration derive from the price of factors of the production and the conditions of access to the market. Moreover, the diseconomies of agglomeration push to the dispersion of economic activities in space.

Krugman's studies have shed light on the forces underlying the processes of agglomeration of the economic activities. Krugman develops a dynamic conception of space, based on the hypothesis of increasing returns. The autor, thus, shows how the interaction of demand, increasing returns to scale and transport costs lead to an endogenous process through giving a type of "center-periphery" of the distribution of the economic activities in space (Krugman, 1991a; 1991b; 1992). The construction of a simple model: two localization zones, two productions, one is agricultural and the other is industrial, allows Krugman to show that the existence of low transport costs, increasing returns to scale and a larget consolidate location decisions. Thus, the conjunction of agglomeration economies, generates an endogenous cumulative and circular process of self-reinforcement of the economic activities. If the author establishes the dependence of the past on economic geography by showing that the initial historical conditions of a system determine its evolution, the author further enriches the analysis by showing that the expectations formulated by the economic agents may lead the system to converge towards a balance which may be different from that to which it should have evolved with regards to the initial historical conditions alone.

Kruman demonstrate that the emergence and the evolution of a "center-periphery" type of industrial localization structure will depend on the arbitration between the sensitivity of the system to the initial historical conditions, the weight of the past and the expectations of the economic agents. From a closely related perspective, Ottaviano and Thisse (2001), shows that the process of adopting a site does not depend systematically on the intrinsic advantage of the site but on agglomeration and the existence of economies of scale. The author also shows that when agglomeration economies have no limits, the process converges to a single site that concentrates all the activities. Other models of geographic economy analyze the effect of the market size and the competition, creating opposing trends in the geography of the economic activity. The mobility of factors of production and the level of transport costs are presented as the determinants of the balance of its forces. Indeed, if transport costs are high, the economic activities tend to be dispersed. On the other hand, for low transport costs, the trend is towards agglomeration and leads to the "center-periphery" configuration (Krugman, 1991a).

The identification of the channels of transmission of externalities and the conditions that allow the internalization of externalities serves as guidline for the conduct of the local growth policies (Delgado and al., 2016). Several studies show that geographical proximity tends to soften the mechanisms of externalities and to facilitate their emergence. However, it would not be sufficient for a firm to locate its activities in an intensive knowledge region in order to benefit from it. The internalization of externalities requires knowledge and skills, and it is necessary to forge links with local economic actors (Zhu and al., 2017).

The dissemination of knowledge can be fostered by various types of relationships between firms and public research organizations (Isaksen, 2015). This may involve the scientific collaboration between the private companies and a public research center, but externalities may also arise from the mere dissemination of knowledge from the public research through publications, patents and conferences. Public research is therefore a potential vector for disseminating externalities.

The developing countries are experiencing great weaknesses in national scientific systems. One possible explanation might be the weakness of technology include weak private and public research efforts and the inadequate technological performance. The technological backwardness in the developing countries can also be explained by the limited resources allocated to research and to innovation and the organizational weaknesses of research and innovation.

It is more appropriate to introduce investment incentives and to establish a regulatory framwork, to foster public research and multiply the effects of training. Growth policy therefore has the role of identifying the issues and the levers on which it can act by improving the efficiency of the education system, the effectiveness of public research institutions and the effectiveness of public funds allocated to research and innovation.

\section{Conclusion}

In the developing countries, the economic activities are agglomerated in large urban areas. The spatial distribution of the economic activities is obviously not done haphazardly, but rather due to companies' definition of their location choices according to all other economic agents. There is a strong link between all the location choices that drive companies to concentrate itself in a space.

The growth policy in the developing countries must be explicitly included in the search for the structural 
adjustment that woukd deeply alter the regional industrial fabric either through the modernization of the traditional industries or through substituting new activities for the endangered activities. They must play a significant role in enabling the least developed countries to catch up the most developed area.

The growth policy must explicitly integrate the geographical dimension with the aim of reducing spatial inequalities (Morgan, 1997). To remain passive in the face of metropolization would risk contributing to excluding whole regions from the production effort of collective wealth and this leads to considerable economic and social costs. It is therefore essential to develop an active policy to promote the potential of low-density regions (Venables, 2005; Isaksen, 2015).

It is important to develop active local policies for each region. It is therefore preferable not to try to overforce the spontaneous mechanisms of the market, nor to oppose the tendency to agglomeration of activities (Martin, 1999; Yifu, 2014).

The local growth policies must be limited to intelligently supporting market forces by developing actions that directly affect business location decisions without, however, restricting areas with high industrial density.

The local growth policies must first determine the strengths and weaknesses of each area in order to determine the most appropriate axes. The public authorities are not in a position to shape the spatial distribution of the economic activities. The institutional reform is the main policy priority.

\section{References}

Azzoni C. 2001. "Economic growth and regional income inequality in Brazil." The Annals of Regional Science 35: $133-152$

Barde S. 2010. "Knowledge spillovers, black holes and the equilibrium location of vertically linked industries." Journal of Economic Geography 10 (1): 27-53.

Billings S.B. and Johnson E. 2016. "Agglomeration within an urban area.” Journal of Urban Economics 91: 1325.

Borowiecki K. 2014. "Geographic clustering and productivity: An instrumental variable approach for classical composers.” Journal of Urban Economics 73 (1): 94-110.

Caragliu A. and Nijkamp P. 2016. "Space and knowledge spillovers in European regions: the impact of different forms of proximity on spatial knowledge diffusion." Journal of Economic Geography 16 (3): 749-774.

Delgado M., Porter M.E and Stern S. 2016. "Defining clusters of related industries." Journal of Economic Geography 16 (1): 1-38.

Kogler D.F., Essletzbichler J. and Rigby D.R. 2017. "The evolution of specialization in the EU15 knowledge space." Journal of Economic Geography 17 (2): 345-373.

Esfahani H.S. and Ramirez M.T. 2003. "Institutions, infrastructure, and economic growth." Journal of Development Economics 70 (2): 443-477.

Fosu A.K. 2013. "Growth of African economies: productivity, policy syndromes and the importance of institutions." Journal of Africain Economies 22 (4): 523-551.

Fritsch M. and Slavtchev V. 2010. "How does industry specialization affect the efficiency of regional innovation systems?." The Annals of Regional Science 45: 87-108.

Isaksen A. 2015. "Industrial development in thin regions: trapped in path extension?." Journal of Economic Geography 15 (3): 585-600.

Kubo Y. 1995. "Scale economies, regional externalities, and the possibility of uneven development." Journal of Regional Sciences 35: 29-42.

Martin P. and Ottaviano G. 2001. "Growth and agglomeration.” International Economic Review 42: 947-968.

Martin P. and Rogers C.A. 1995. "Industrial location and public infrastructure." Journal of International Economics 39: 335-351.

Martin P. 1999. "Public policies, regional inequalities and growth." Journal of Public Economics 73 (1): 85-105

McCormick D. 1999. "African enterprise clusters and industrialisation: theory and reality." World Development 27: 1531-1551.

Morgan K. 1997. "The learning region: Institutions, innovation and regional renewal.” Regional Studies 31: 491504.

Mori T. and Smith T.E. 2015. "On the spatial scale of industrial agglomerations." Journal of Urban Economics 89: 1-20.

Puga D. 1999. "The rise and fall of regional inequalities.” European Economic Review 43: 303-334.

Rey S.J. and Janikas M.V. 2005. "Regional convergence, inequality, and space.” Journal of Economic Geography 5 (2): $155-176$

Rosenthal S-S. 2001. “The determinants of agglomeration.” Journal of Urban Economics 50: 191-229.

Sala H. and Trivín P. 2014. "Openness, investment and growth in Sub-Saharan Africa." Journal of Africain Economies 23 (2): 257-289.

Salinas G., Gueye C. and Korbut O. 2015. “Impressive growth in Africa under peace and Market Reforms.” Journal 
of Africain Economies 24 (1): 1-25

Zhu S., He C. and Zhou Y. 2017. "How to jump further and catch up? Path-breaking in an uneven industry space." Journal of Economic Geography 17 (3): 521-545.

Storper M., 1995. "The resurgence of regional economies, ten years later: The region as a nexus of untraded interdependencies." European Urban and Regional Studies 2: 191-221.

Venables A.J. 2005. "Spatial disparities in developing countries: cities, regions, and international trade." Journal of Economic Geography 5 (1): 3-21.

Vermeulen W. 2017. “Agglomeration externalities and urban growth controls.” Journal of Economic Geography 17 (1): 59-94.

Yifu Lin J. 2014. "Industrial policy revisited: a new structural economics perspective.” Revue d'Économie de Développement 22 (3): 51-70.

Krugaman, P. 1991a. "Increasing returns and economic geography." Journal of Political Economy 99: 483-99.

Krugman P. and Venables A.J. 1995. "Globalization and the inequality of nation." The Quaterly Journal of Economics 110 (4): 857-880.

Henderson V., Shalizi Z. and Venables A.J. 2001. "Geography and development.” Journal of Economic Geography 1: $81-105$

Prager J.-C. and Thisse J.-F. 2009. “Les enjeux géographiques du développement économique.” Agence Française de Développement, France.

Borensztein, E., Gregorio, J. and Lee, J-W. 1994. "How does foreign direct investment affect economic growth?." Journal of International Economics 45: 115-135.

Bell, M. and Pavitt, K., 1996. "Technology accumulation and industrial growth: contrats between developed and developing Countries." Industriel and Corporate Change 2: 157-210.

Blomström, M. and Kokko A. 2003. "The Economic of foreign investment incentives." National Bureau of Economic research (NBER) Working Paper 9489.

Kokko, A. 1996. "Productivity spillovers from competition between local firm and foreign affiliates." Journal of International Development 8: 517-530.

Glaeser, E., Kallal, H., Scheinkman, J. and Shleifer, A. 1992. "Growth in cities." Journal of Political Economy 100: 1126-1152.

Barro R.J. 1990. “Government spending in a simple model of endegeneous growth.” Journal of Political Economy 98 (S5): 103-125.

Ottaviano G. and Thisse J.F. 2001. "On economic geography in economic theorys increasing returns and pecuniary externalities." Journal of Economic Geography 1: 153-179.

Baldwin R., Martin P. and Ottaviano G. 2001. "Global economic divergence, trade and industrialisation: the geography of growth take-offs." Journal of Economic Growth 6: 5-37.

Fujita, M. and Thisse, J-F. 1996. "Economics of agglomeration." Journal of Japanese an International Economics 10: 339-378.

Henderson V., Shalizi Z. and Venables A.J. 2001. "Geography and development.” Journal of Economic Geography 1:81-105.

Krugaman, P., 1991a. "Increasing returns and economic geography.” Journal of Political Economy 99: 483-99.

Krugaman, P. 1991b. "History and industry location: the case of manufacturing Belt." American Economic Review 70 (5): 950-959.

Krugaman, P., 1992. "A dynamic spatial model.” National Bureau of Economic research (NBER) Working Paper 4219.

Ottaviano G. and Thisse J.F. 2001. "On economic geography in economic theorys increasing returns and pecuniary externalities.” Journal of Economic Geography 1: 153-179. 